\title{
Comparative Carcinogenesis
}

National Cancer Institute

\section{Source}

National Cancer Institute. Comparative Carcinogenesis. NCI Thesaurus. Code C19607.

The study of the similarities and differences between different living organisms of the process by which normal cells are transformed into cancer cells. 